\title{
Tilting at a Windmill? The Conceptual Problem in Contemporary Peace Science
}

\author{
Will H. Moore
}

\begin{abstract}
Peace scientists such as Kenneth Boulding, Ted Gurr, Thomas Schelling, and Charles Tilly were fastidious in their use of abstract concepts free of the political baggage that politicians, policymakers, and pundits necessarily foist upon the terms in the rough and tumble world of politics. Too much contemporary peace science fails to follow their lead. This essay describes this problem and proposes a useful heuristic to help us improve.
\end{abstract}

\section{Keywords}

Concepts, Extremism, Islamism, Science, Social Science, Terrorism

\section{Concepts: Why the Words Peace Scientists Use Matter}

One need embrace neither George Orwell (1946) nor Jürgen Habermas (1981) to appreciate that politicians, policymakers, and pundits use words to mobilize support. Of particular interest to those of us engaged in the scientific study of conflict and peace, demonizing "the enemy" and lionizing one's own virtues are part and parcel to the practice of politics that we study, though unlike other students of politics, our field of inquiry includes the loss of life, limb and property, sometimes on a very large scale. I submit to you that those of us in the peace science community have been failing, quite glaringly in my view, of late to appreciate that the concepts we use in our theories are

School of Politics and Global Studies, Arizona State University

\section{Corresponding author:}

Will H. Moore, School of Politics and Global Studies, Arizona State University, P.O. Box 873902, Tempe, AZ 85287-3902

Email:whmooreasu@gmail.com 
not immune from the political usage of words in daily politics. Put plainly: when we use terms in our theories that are used by politicians, policymakers, and pundits, we cannot escape the political baggage these words bring with them.1.

As far as I can tell, the current problem has not always been this dire. Indeed, peace scientists such as Boulding (1962), Schelling (1966), Gurr (1970), Dahl (1971), Tilly (1978), and Blalock (1989) consistently employed abstract concepts divorced from the terms used by politicos 2 . to describe the same events, phenomena and processes. As I trained to enter the field and read the works of these, and other, scholars I was struck by their use of abstract concepts, which was notably different from those I had read in in the press and journals such as Foreign Affairs during high school and college. I submit that this practice has considerable scientific value; we would do well to push one another to embrace it.

We know the rule for concepts: theory requires abstraction. When we theorize we should seek to determine whether a given theory still holds when we increase the generality of our concepts (e.g., Cohen and Nagel 1934, pp. 14-18, 21-22, 223-244). More pithily, we are taught the dictum: don't use proper nouns.

While that is sound advice for all practicing scientists, those of us who are social scientists, and especially those of us who study conflict and peace, bear an additional burden. Our work is normatively laden. Because words are a primary tool used by the politicos who engage in political competition, and the journalists who cover them, we have an additional reason to produce abstract concepts not (yet)3. used in public debates about conflict and peace. Politicos are professional wordsmiths who literally use words to mobilize support across politically salient cleavages. They dominate public conversation, as they should,4. and we cannot, in the short run, hope to successfully compete in that arena. Put directly: we should avoid the pejorative words that politicos and journalists use.

Before moving into the argument I offer, for your consideration, quotes from some of the works cited above. Boulding (1962, p. vii) explains that his book

does not deal, except by way of occassional illustration, with the current historical situation in detail, for it has been inspired not only by a practical end but by the belief that applied science cannot succeed unless it guides its empirical study by reins, however loose, of abstract theory. Although a theory of war and peace and of international relations is perhaps the most important part of this work, it is by no means the whole of it, because of another conviction which grew in my mind... in 1944 and 1955. This was the conviction that, in order to develop a theoretical system adequate to deal with the problem of war and peace, it is necessary to cast the net wider and to study conflict as a general social process of which war was a special case.5.

One need not subscribe to Boulding's conviction about theorizing at that highly general level to appreciate the importance of abstraction and generalization that guided him in his craft.

Both Gurr and Tilly address the ethical issue I highlight. Consider first Gurr (1970, pp. $\mathrm{xx}-\mathrm{xxi})$. 
A general explanation of political violence can become a guide to action as well as comprehension... Social theory can be put to unethical as well as ethical ends, and an author has little control over the use of his work short of refusing to publish... This book is as likely to be read by rebels as by rulers and suggests as many effective courses of action for one as for the other.

He goes on to elucidate what dissidents, and then states, can draw from it.

Tilly (1978, p. 5) notes that the very people we study consider themselves experts on the topic and do not appreciate being told that they are not. He continues:

It is more delicate than that. Deep in every discussion of collective action stirs the lava of a volcanic eruption: collective action is about power and politics; it inevitably raises questions of right and wrong, justice and injustice, hope and hopelessness; the very setting of the problem is likely to include judgments about the right to act, and what good it does.

Gurr and Tilly were explicitly self-aware of the ethical issue at the heart of this essay. Those of us who choose to participate in peace science must shoulder that burden and press the other members of our community to do the same. We all know this is so, and by raising it I risk offending the reader. I am willing to take the risk because we do not yet widely recognize that being self aware about these ethical issues has an important implication. Though neither Gurr nor Tilly explicitly discuss the importance of using abstract concepts that generate distance from contemporary political debate, their work, like that of the other luminaries cited above, did so. We will do well to follow their example.

\section{Intersubjective Agreement: Discourse does not Occur in a Vacuum}

When we use the words employed by politicos as concepts in our theories, we engage in a political act, regardless of whether we intend it as such or recognize that we do so. Why? The foundation of natural language is intersubjective agreement about grammar and the definitions of words. Both grammar and definitions change over time (i.e., in the long run), but the fact that they are fixed in the short run makes communication possible. Below I leverage this distinction between the fixed short run and fluid long run. For now let us focus on the short run.

Many of you have likely encountered a student who insisted that a given definition of a term is flawed and wanted to redefine the term in some way that struck you as unlikely to gain wide circulation. You presumably counseled the student not to pursue that path. Why? Because you (implicitly) recognized the difference between the short and long run in discourse and were dubious about that student's ability to lead a revolution.

This is all rather banal, and I share it as backstory to which I return below. Let me now offer a personal digression that further sets the stage for what is to come. 


\section{Diary: Selecting "Dissident" \& "State"}

I had the good fortune to be a student in Gurr's Political Violence seminar during the first semester of my graduate studies. During the discussion of Why Men Rebel he shared with us two regrets he had about the book. First, were he able to have a do-over, in the title and throughout, he would substitute the word people for the word men. Second, although he had discussed state coercion, he had failed to discuss state terror. I took from that discussion that we tend to be trapped by the implicit cultural and political assumptions of our time, and I developed my own conviction: scientists must strive to transcend that.

To that end I wrestled, over the following year or so, with the issue of what terms I should adopt to identify the two central actors that I was certain would play a role in my theorizing:

1. Groups of people who band together to challenge government (policies) and adopt extra-systemic means to do so, and

2. The governments that seek to sustain the status quo in the face of such challenges.

During that time I began to consume the news about conflict and peace through new eyes. I had long appreciated that politicos use words as tools to mobilize, but the readings in Gurr's seminar showed me that social scientists could use them to develop causal theories. The literature provided me with new tools to think about what was reported in the news. I decided I had a problem: I needed to identify terms to describe those two groups that were not being used by politicos. The term state was fairly easy to identify and select. Then Lichbach (1987) was published, and I found in it dissident. I tinkered for another year or more before settling, but my problem was solved.

I have a fantasy in which this is a rite of passage that all peace scientists go through: whatever their specific domain of inquiry, during the early years of their PhD study budding peace scientists wrestle with the ethical issues discussed above and bandy about concepts that permit them to successfully negotiate the shoals. Experience, of course, lays ruin to fantasy.6.

\section{Representative Problems: Terrorism/ist, Extremism/ist, Islamism/ist, and (in)Stability}

These are but four terms that politicos use and we should not: terrorism/ist, extremism/ist, Islamism/ist and (in)stability. Below I discuss each term, but first I want to use the search engine images. google. com to substantiate my claim about pejorative labels in public discourse.7. Three days prior to my address at the 2014 Peace Science meeting I entered these five terms into that engine, and took a screen capture. Figures 1 through 5 display the results. I suspect the reader will agree that this face validity exercise is consistent with my point.

The terms terrorism and terrorist are the objects of a well known definitional debate (e.g., Schmid 2004, 2012), and I will not try to summarize it here (see Easson and Schmid 2011). I will observe that the suffix -ist is commonly defined as denoting an adherent of a system of beliefs, principles, etc., and is often expressed by nouns ending in -ism. 


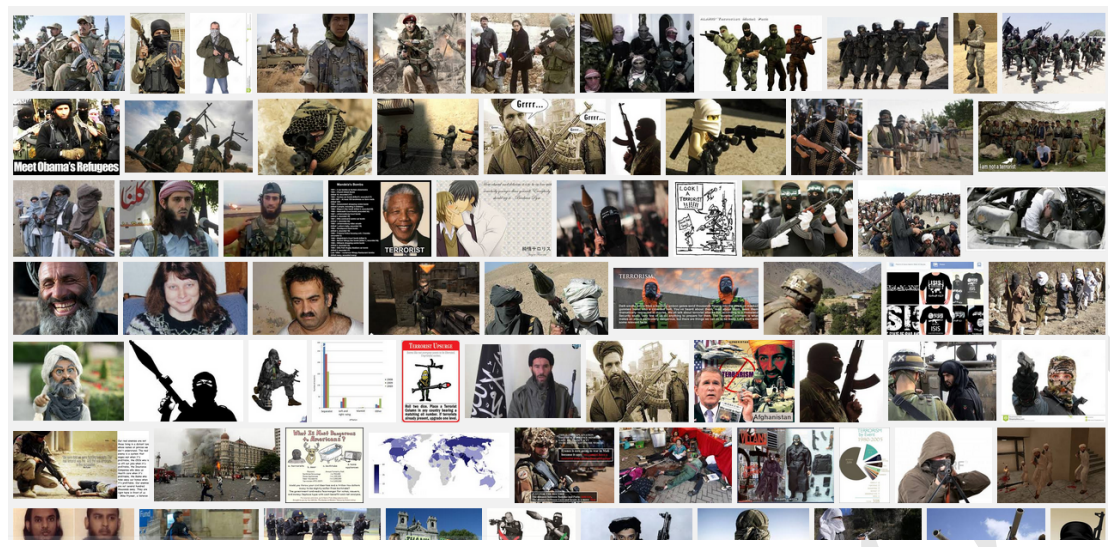

Figure 1. Terrorist: Google Images, November 2014

This lays bare the rhetorical value of the term terrorist: by identifying their system of beliefs as terror, politicos are half way home denying that the dissidents so labeled have political objectives, policy proposals, etc. Rather than use the terms terrorism or terrorist in my research, I speak of "a state terror campaign," "dissidents using terror tactics" and similar locutions. To embrace abstract theorizing I rely upon Schelling's (1966) and Stohl's (1983) discussions to inform my conceptualization of terror as a coercion tactic (Moore et al. 2011), but many other abstract conceptualizations are available. Yet providing a precise, abstract definition is not enough. Dropping the -ism and -ist is not difficult, and doing so facilitates scientific practice by putting distance between it and the rhetorical fray of politicos.

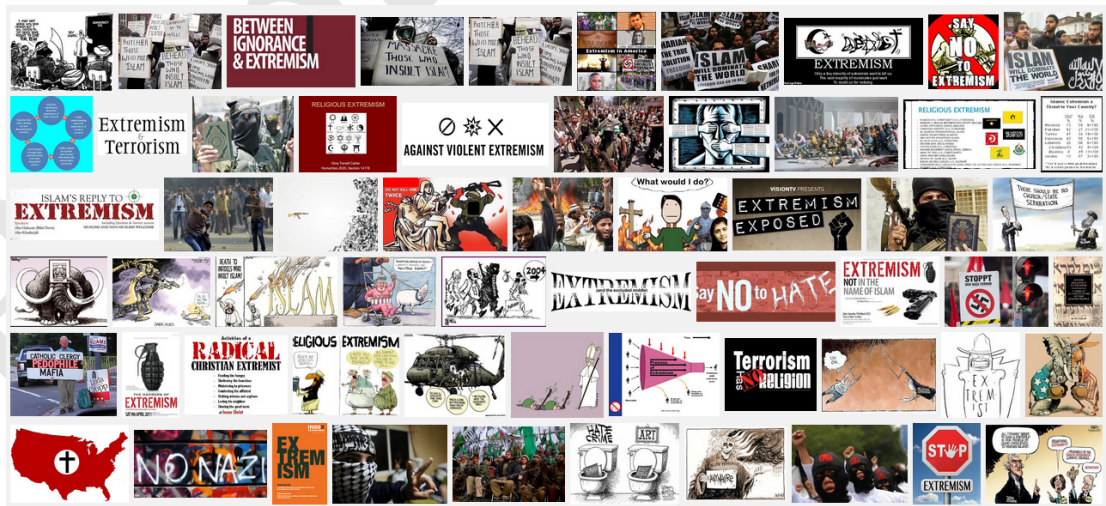

Figure 2. Extremism: Google Images, November 2014

The terms extremism and extremist suffer from a lighter version of affixing the -ist and -ism suffixies to terror: subscribing to an extreme belief system is less noxious than 
subscribing to a terror belief system. Yet, as Figure 2 demonstrates, the term, as used in public discourse, is pejorative.

When peace scientists use the term they tend to either leave it undefined, leaving the reader to decide whether the pejorative use in public discourse or some other meaning is intended. Any term can be defined so as to make it precise, and peace scientists might adopt a unidimensional spatial model and define extremists as those who advocate policies that are far from the status quo (e.g., perhaps more than two standard deviations). They might alternatively define extremists as supporters of a group that has less than 10 percent of the density's support. Other variations surely exist. Yet trying to define precisely terms used by politicos runs afoul of the fact that the resultant definition is at odds with the usage in political discourse and that usage is pejorative.

Consider, for example, another term that is used very differently in public and scientific discourse: rational. As an economics major in college I quickly came to learn that when my professors' used the term rational they meant something distinct (and considerably more precise) from what my family and friends meant when they used the term. Scientific discourse is rife with such examples.8. Does this demonstrate that the problem I have identified is not our use of these terms, but instead that members of the scientific community must do a better job of pressing one another to define their terms? Indeed, the considerable success of the public v. scientific usage of the same term demonstrates that I am barking up the wrong tree. Right?

It does not. The differences are:

1. Pejorative labeling;

2. Emotional costs imposed by conflict.

When we introduce our undergraduate students to the specialized usage of terms like rational or correlation in scientific discourse we are not expecting them to abandon pejorative labels that are tied to strong emotional responses. Because of that, we require only that they recognize the context in which they are so that they can decide which usage is appropriate. Parsing meaning as a function of context is something at which human beings excel, and thus many students are able to do so without much difficulty.9. When we ask students, policymakers, or colleagues outside of our field, however, to do such parsing with terms used to discuss conflict and peace we are placing much greater demands on them. I do not think those demands are reasonable. Indeed, I believe we delude ourselves should we argue that peace scientists can routinely parse such meanings. I am certain, however, that many of our colleagues who study conflict and peace outside of the scientific community will struggle to meet such expectations.10.

The terms Islamism and Islamist are quite reasonably given the -ism and -ist suffix: on its face the words denote people who subscribe to a belief system informed by Islam. As such, these terms initally appear to be unproblematic for peace scientists. The trouble begins when we consider usage of these terms during this specific historical moment. Absent the successful mobilization of groups like Al Qaeda that have as a goal the establishment of a global caliphate based on an unorthodox interpretation of the Mulsim faith coupled with that mobilization being a function, in part, of their use of terror tactics, these terms would not be problematic. They would also not be associated with 


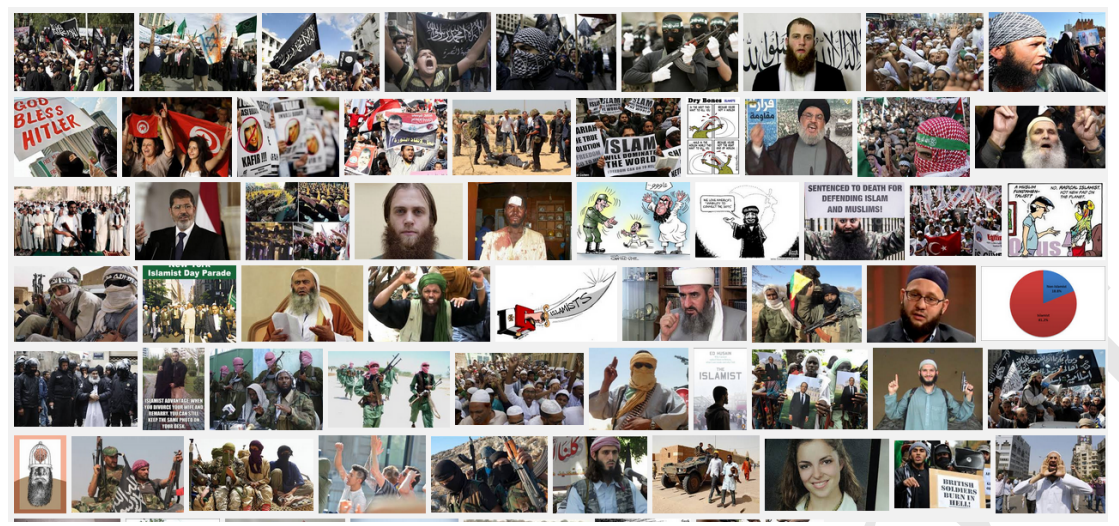

Figure 3. Islamist: Google Images, November 2014

the imagery in Figure 3, nor would it be readily apparent why anyone studying peace and conflict would be likely to want to use those terms. Yet, Al Qaeda and smiliar groups have successfully mobilized, and those of us who use the English language to communicate cannot escape the pejorative usage of those terms by so many English speaking politicos.

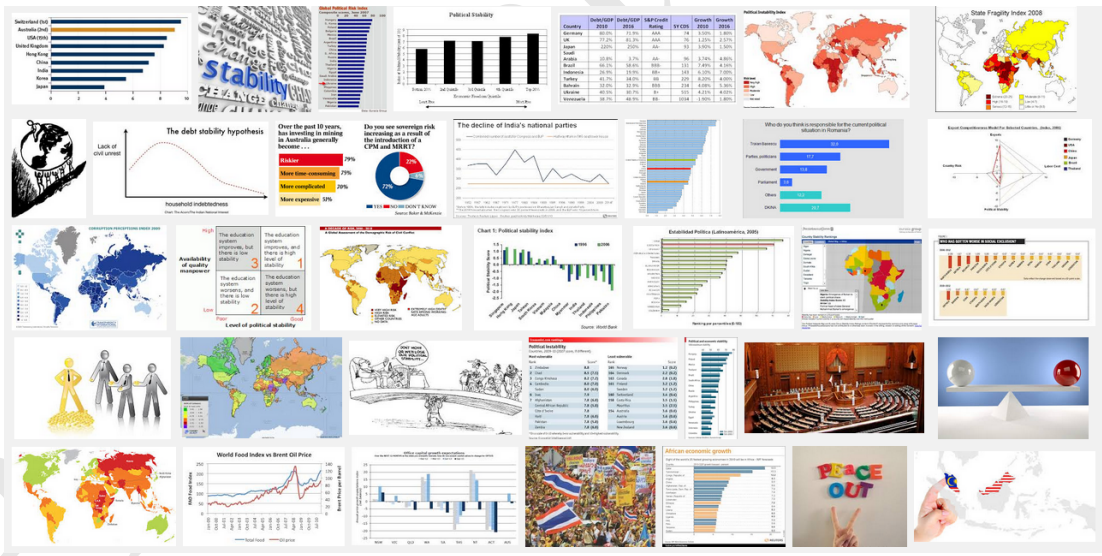

Figure 4. Stability: Google Images, November 2014

The terms stability and instability represent another problem: status quo bias. Any given status quo partitions economic, political, and social power. All states share a common goal of defending the domestic status quo. Stability represents order and predictability. Order and predictability have positive connotations. Instability connotes the opposite of order and predictability, and is thus pejorative. If we give it a little thought, it is not difficult to see that stability maintains the status quo while instability threatens it. Yet, in public discourse the proportion of the public who will make that association will 
be small. This is why (in)stability is so useful to politicos in power, and why we must not use it. Figures 4 and 5 are quite consistent with my argument.

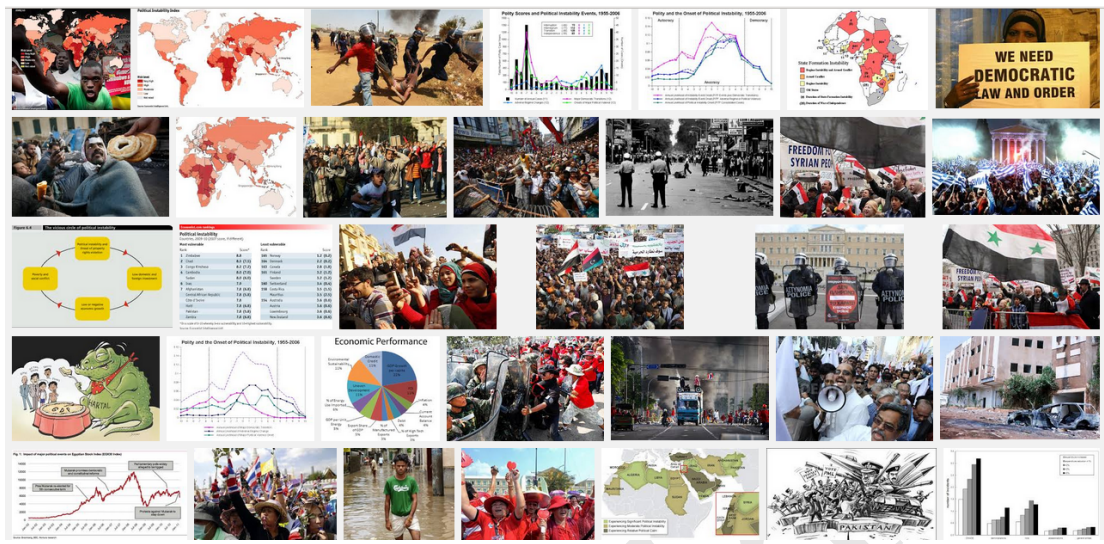

Figure 5. Instability: Google Images, November 2014

\section{A Counter-Factual Illustration}

"A face validity check is nice," I imagine the reader may be thinking, "but I need an example from the literature." Quite right. A single example is sufficient, but I invite the reader to select an issue of Journal of Conflict Resolution, Journal of Peace Research, or many others, search for one of the terms above (or one of your own choosing), and try the exercise below on your own.11. I promise, you will not find the exercise terribly difficult.

Let us examine what it might look like if we replace troublesome terms used by journalists, pundits and politicos with concepts they do not use. Consider this passage from Shapiro and Fair's (2010) "Understanding Support for Islamist Militancy" (emphases mine):

These policy prescriptions rest on-and indeed reflect-four powerful conventional wisdoms. The first is that poverty is a root cause of support for militancy, or at least that poorer and less-educated individuals are more prone to militants' appeals. The second is that personal religiosity and support for sharia (Islamic law) are strongly correlated with support for Islamist militancy. The third is that support for political goals espoused by legal Islamist parties predicts support for militant organizations. The fourth is that those who support democracy-either in terms of supporting democratic processes such as voting or in terms of valuing core democratic principles-oppose Islamism and militancy.

Let's try it using abstract concepts of the type Boulding, Gurr, Schelling, Tilly and others might use (denoted in italics). 
These policy prescriptions rest on-and indeed reflect-four powerful conventional wisdoms. The first is that poverty is a root cause of support for militancy, or at least that poorer and less-educated individuals are more prone to militants' appeals. The second is that personal religiosity and support for religious law are strongly correlated with support for dissident militancy among people of faith. The third is that support for political goals espoused by legal dissident parties predicts support for militant dissident organizations. The fourth is that those who support democracy-either in terms of supporting democratic processes such as voting or in terms of valuing core democratic principles-oppose religious political mobilization and militancy.

What do you think? Which version is more useful to scientific discourse (i.e., the construction of theories of politics, and the empirical testing of hypotheses derived from those theories)?

Now let's replace the word militant.

These policy prescriptions rest on-and indeed reflect-four powerful conventional wisdoms. The first is that poverty is a root cause of support for dissident groups that use violence, or at least that poorer and less-educated individuals are more prone to the appeals of such groups. The second is that personal religiosity and support for religious law are strongly correlated with support among people of faith for dissident groups that use violence. The third is that support for political goals espoused by legal dissident parties predicts support for dissident organizations that use violence. The fourth is that those who support democracy-either in terms of supporting democratic processes such as voting or in terms of valuing core democratic principlesoppose religious political mobilization and violent dissent.

Is that any better?

While the particular political cleavage that Shapiro and Fair explore in their study is religious, they fail to explain why religion is a cleavage that is distinct from other cleavages.12. This represents a generic problem in studies of ethnic conflict: we often implicitly assume an essentialism, that conflicts where mobilization occurs over an ethnic cleavage are importantly distinct from those where mobilization occurs over other cleavages. In effect, concepts that cover the special case of mobilization over a religious cleavage (such as Tilly's (1978, pp. 62-4) catnet, for example) are dismissed because they are presumably too general. That is, peace scientists who study "ethnic conflict," "terrorism," "counter-insurgency," "civil war," and so forth are implicitly arguing that the conflict processes that unfold in the type of dissident-state interaction they are studying is meaningfully distinct from the conflict processes that unfold in other forms of dissidentstate interaction. While I do not share such a view, peace scientists who wish to advance such an argument should be expected to make an explicit case about why the processes they are studying in the specific type of dissident-state interaction differ meaningfully from the general pattern of dissident-state interactions. 
My best guess about why many peace scientists eschew abstract, general theorizing is nicely captured by Barbara Geddes (2003), who observes that research in political science tends to be driven by contemporary political events, with something like a three to five year lag. This interest in current events produces our strong tendency to ask research questions using the terms that we find in the public discourse. This weakens the scientific enterprise.13. When there is a plain, superior alternative available-adopt abstract, general concepts to build theory-why sustain our present habit of grafting the terms used by politicos onto our theories?

The practice of science is a collective enterprise. Those of us who self identify as community members recreate the norms of science. In the short run those norms are structure, but in the medium to long run that structure shifts in response to the debates the community undertakes about best practices. The bar is presently too low: we are giving one another a pass when it comes to the concepts we employ. By expecting more of one another we can improve.

Here's the takeaway: when we eschew the terms used by politicos and embrace more abstract concepts, peace science is improved in two ways at no cost:14.

1. Our theories are more general;

2. We avoid political baggage

Both of these goals warrant our attention.

\section{Got Heuristic?}

How might we change? Here is a quick check we can all undertake to determine whether a concept is appropriate: do journalists, pundits and politicos use it? If so, it is tainted. Don't use it in your research.

\section{Au Contraire: The Case for Engaging the Fight}

Some will concur with my claim that terms like terrorism/ist, extremism/ist, Islamism/ist, and (in)stability are often used in biased, overly status-quo oriented, sloppy, and otherwise problematic ways, yet claim that rather than foreswear their usage peace scientists must not cede those terms to politicos and journalists, but instead use these terms well, and thereby change public debate.15. To concede the terms is, in effect, capitulation, a form of retreat behind the walls of the ivory tower, and thus directly at odds with my claim about the importance of concepts.

This is an important counter-claim. To address it I need to distinguish between the short and long runs. For the short run I disagree: as I argue above, public discussion is necessarily dominated by political elites and they use terms for an entirely different purpose than we do.

What of the long run? Here I seek an assist from John Maynard Keynes who closed his 1936 book, The General Theory of Employment, Interest and Money, this way:

the ideas of economists and political philosophers, both when they are right and when they are wrong, are more powerful than is commonly 
understood. Indeed the world is ruled by little else. Practical men, who believe themselves to be quite exempt from any intellectual influences, are usually the slaves of some defunct economist. Madmen in authority, who hear voices in the air, are distilling their frenzy from some academic scribbler of a few years back. I am sure that the power of vested interests is vastly exaggerated compared with the gradual encroachment of ideas. Not, indeed, immediately, but after a certain interval; for in the field of economic and political philosophy there are not many who are influenced by new theories after they are twenty five or thirty years of age, so that the ideas which civil servants and politicians and even agitators apply to current events are not likely to be the newest. But, soon or late, it is ideas, not vested interests, which are dangerous for good or evil.

The concepts scientists use do not impact public discussion in real time, but instead, a generation or two later. We teach the courses that tomorrow's leaders take in college, and the concepts, theories and findings we are debating today find their way into undergraduate coursework roughly a decade later. Those students become leaders roughly two decades later.16. At the conceptual level especially our contribution to public discourse occurs over the long run. In other words, we must adopt what is, in effect, a guerrilla tactic: conceding the ground during the short run, only to take it over the long run.

Two issues require attention. First, one might ask what happens when we shift forward a generation? Do I imagine a world in which politicos now speak like social scientists? I do not. Krugman (1994) chronicles politicos co-opting academic terminology and theory, in some cases with a considerable assist from faculty, demonstrating that today's longrun becomes tomorrow's short-run. To be sure, future generations of peace scientists will have to confront tomorrow's politicos just as we do today's. Such is the nature of dynamic systems. Yet, this dynamism does not makee Keynes wrong.17.

That said, let us turn second to specific examples of the lagged generational impact of ideas upon a topic from peace science: riots. Echoes of the largely discredited ideas of Le Bon (1897), made into social scientific theory by Smelser (1962) among others, that crowds have a dynamic that tends to lower individuals' inhibitions to the lowest among them can still be found today (Dalrymple 2011; Stein 2015). Yet, while bemoaning the momentary collapse of "civilization" in 2011 London and 2015 Baltimore, both authors take care not to paint all members of "the crowd" with Le Bon's broad brush. That is, these politicos temper their punditry in deference to the work of Gurr and others that emphasizes the complex interactions among protestors, police, politicians and the media that produce riots (for a review see Wilkinson 2009). More directly to Keynes's claim, plenty of the media coverage of the events in 2011 London (e.g., Editors 2015a) and 2015 Baltimore (e.g. Editors 2015b; Badger 2015; Mmari et al. 2015) reflect the extent to which research by peace scientists writing in the 1970s and 1980s influences contemporary understanding. I trust the reader is sufficiently familiar with additional politicos' statements about protests and riots that I need not elaborate and can 
observe that contemporary public conversation illustrates both the challenge and promise contained in Keynes's observation.

\section{Parting Words}

I cannot tell you how many times during my career a researcher who does not study peace science has said to me something akin to: "Well, at least you don't have to explain the importance of studying your topic. I study X, and I am always having to explain why anyone should care." Yet the advantage conferred by this prima facie importance is counter-balanced by a burden. Our topic is also part and parcel of political conflict, and this means that - in the short run - the discourse of politicos, who necessarily grind axes, will overwhelm our own debates with respect to the meaning of terms.

We are idea-smiths, and the concepts that we employ are central to our craft. Our collective output has a far reaching impact, but it occurs in the long run. Politicos, on the other hand, are exercising power in real time and the short run. Peace scientists should and will engage public debate, conduct research funded by governments, and consult with policymakers. When we wear that hat it would be counter productive to employ the specialized langauge we use to communicate with one another and expect those audiences to follow. Just as we require our students to learn to adopt different definitions of words depending on context, we too must expect it of ourselves. We have invested heavily in intellectual capital and are well overqualified to be able to move back and forth across specialized v. politico discourse. Arguments that if we want our resarch to be relevant to policy makers we must theorize using the terms used by politicos are folly.

In closing I wish to observe an exciting development that will facilitate our ability to engage and influence policy makers. The Monkey Cage of The Washington Post is edited by political scientists, and publishes content exclusively produced by political scientists and other social scientists who study politics. Two of the contributors at The Upshot of The New York Times are political scientists, and the blog Political Violence@a Glance has a wide readership outside of academia.18. The data journalism site fivethirtyeight.com got its start producing ensemble forecasts of US Presidential elections. In short, there is considerable reason for optimism that peace science will increasingly gain relevance in public affairs. Writing in 1936 Keynes could not have imagined the value a Masters degree in economics would provide a prospective government bureaucrat: the temporal lag between scholarly debate in economics and policy impact is surely shorter today than it was in the 1930s. I fully anticipate that the relevance of peace science (and political science more broadly) to policy makers will grow over the coming decades much as it did for economics during the post World War II era. And I expect that those who construct their theories using the terminology employed by politicos are considerably less likely to see their work contribute to progress in the field over the long run than those who eschew that terminology in favor of abstract concepts. 


\section{Notes}

1. To be sure, some researchers who study conflict and peace are political hacks masquerading, perhaps quite unaware, as scientists, or otherwise deploying tools of our trade to advance political goals in the name of country, "civilization," self aggrandisement, or what have you. I am disinterested in these "scholars" and wish to address those of us who are engaged in the practice of science.

2. By politicos I am referring to politicians (including their staff), policymakers (i.e., government bureaucrats), and pundits.

3. Below I make clear the purpose of this paranthetical insert.

4. I am opposed to a scientific technocratic order.

5. He then explains that not only this book, but his founding of the Journal of Conflict Resolution and a center at the University of Michigan were also the fruit of this convitction.

6. The community of peace scientists who study intrastate conflict and peace appear to lag behind those who study interstate conflict and peace. State A and State B have long been staples in that literature, and I am hard pressed to identify many examples of terms in that area of inquiry that are similar to those I discuss below. This may, however, reflect an information asymmetry: I am much better versed in the former than the latter.

7. The search engine returns images based on a page rank algorithm that measures the extent to which the page in question has ties to other pages on the Wolrd Wide Web. The result, then, is images ordered by the rank of their pages, and for this exercise provides a useful measure of the imagery most commonly associated with a term.

8. When I teach undergraduate research methods I frequently warn the students that terms like correlation have precise meanings that are different from how they have used these terms.

9. I have spent my career teaching at large public universities in the US, and my experience has been that many, though not most, have both the ability and the interest in doing this well. I fantasize that the vast majority of students at selective private universities in the US have both the ability and interest in doing so, but have no experience upon which to draw.

10. Interestingly, our colleagues who work within critical and post-modern paradigm and study conflict and peace will be able to do so well, though I suspect most would agree with the general tenor of my argument and also reject terms used by politicos in what they might refer to as the dominant discourse.

11. Inevitably, I have to select a publication to "pick on," and I have selected one of Jake Shapiro's articles. I selected Jake's work for several reasons. One, Jake does excellent work. Two, despite how much I value reading his work, I have on multiple occassions winced at his use of concepts like those noted above. Finally, at a workshop sponsored by the START Center at University of Maryland in January 2014, Jake began his presentation pointing out that he had once been told that if you are going to pick a fight, select someone who is worth fighting with (or something to that effect). I made a mental note: Jake is fair game, and I hope this essay influences his work going forward. I could, of course, have selected the work of any of a score or more peace scientists to illustrate.

12. Jake Shapiro was kind enough to explain that he and Christine Fair spent considerable time debating whether to use Islamic militants and Islamism in their article. They decided that, because there were many other dissident actors employing violent tactics in 2007 Pakistan that 
were neither advocating sharia law nor making religious appeal, these terms best reflected the intersection of the constellation of specific actors and policy positions that they were trying to describe.

13. Please note that I am not suggesting we abandon current events as stimulation for our research questions. Rather, I am suggesting that we recognize the pitfall of grafting the terms used by politicos in their debates about current events and shun them in favor of abstract concepts that have greater scientific value.

14. Some might argue that peace scientists who embrace abstract concepts will find it more difficult to get their research funded or have less impact upon policymakers. I suspect most readers will agree with me that such an argument about funding is self evidently problematic. The latter argument will hold for scholars who expect policymakers to engage their scholarship directly. I have the impression that some (many?) in fact do, but to me this is silly. Has any science become influential due to non-expert consumption of its peer review publications? Of course not. Journals like Nature, Science and The New England Journal of Medicine have press releases for a reason, and we are starting to see some of that in political science. More gnerally, we must (find agents to) translate our technical work into publicly digestible form, and in the conclusion I briefly touch on this issue.

15. I am indebted to Page Fortna for this point.

16. In Washington, DC, Congressional staffers can be influential within a decade of graduation, but I have no idea whether this is common in other political systems, and am content to consider it an exception that supports the rule (i.e., an outlier): as a cohort our students do not obtain leadership positions in their careers and communities until their 40s.

17. Indeed, Krugman titled chapter eight of his book "In the Long Run Keynes is Still Alive."

18. Full disclosure: I am an editor at Political Violence @ a Glance.

\section{Acknowledgements}

Presidential Address to the 2014 annual meeting of the Peace Science Society (International). Andy Beger, Baer Braumoeller, Raul Caruso, Erica Chenoweth, Courtenay Conrad, Christian Davenport, Page Fortna, Jillienne Haglund, Danny Hill, Kim Frugé, T. David Mason, Cliff Morgan, Jake Shapiro, David Siegel, Jeff Weber and Ryan Welch provided helpful feedback.

\section{References}

Badger E (2015) The long, painful and repetitive history of how baltimore became baltimore. The Washington Post April 29(http://wpo.st/HHEH0).

Blalock HM (1989) Power and conflict: Toward a general theory. Thousand Oaks: Sage Publications.

Boulding KE (1962) Conflict and defense: A general theory. New York: Harper.

Cohen MR and Nagel E (1934) An introduction to logic. New York: Harcourt, Brace and Company.

Dahl R (1971) Polyarchy: Participation and Opposition. New Haven: Yale University Press.

Dalrymple T (2011) It's fun to smash things: And in britain, there is little civilisation left to stop you. The Spectator August(http://www.spectator.co.uk/issues/august-13-2011/). 
Easson JJ and Schmid AP (2011) 250 plus academic, governmental and intergovernmental definitions of terrorism. In: Schmid AP (ed.) The Routledge Handbook of Terrorism Research. London: Routledge,, pp. 99-200.

Editors T (2015a) Uk riots 2011. The Guardian http://www.theguardian.com/uk/london-riots.

Editors T (2015b) Why freddie gray ran. The Baltimore Sun April 25(http://fw.to/Gp1Y23H).

Geddes B (2003) Paradigms and Sand Castles: Theory Building and Research Design in Comparative Politics. Ann Arbor: University of Michigan Press.

Gurr TR (1970) Why Men Rebel. Princeton: Princeton University Press.

Habermas J (1981) The Theory of Communicative Action: Reason and Rationality of Society. Boston: Beacon Press.

Krugman PR (1994) Peddling Prosperity: Economic Sense and Nonsense in the Age of Diminished Expectations. New York: WW Norton.

Le Bon G (1897) The crowd: A study of the popular mind. London: Fischer.

Lichbach MI (1987) Deterrence or escalation? the puzzle of aggregate studies of repression and dissent. Journal of Conflict Resolution 31: 266-297.

Mmari K, Blum RW and Marshall B (2015) Here's one way baltimore teens are worse off than poor youth in nigeria and india. The Washington Post April 30(http://wpo.st/PCEH0).

Moore WH, Bakker R and Hill DW (2011) How much terror? dissidents, governments, institutions and the cross-national study of terror attacks. URL http://ssrn.com/abstract= 1977262. SSRN Working Paper, http://ssrn.com/abstract=1977262.

Orwell G (1946) Politics and the english language. Horizon April. Available online at: http: //wikilivres.ca/wiki/Politics_and_the_English_Language.

Schelling TC (1966) Arms and Influence. New Haven: Yale University Press.

Schmid AP (2004) Frameworks for conceptualising terrorism. Terrorism and political violence 16(2): 197-221.

Schmid AP (2012) The revised academic consensus definition of terrorism. Perspectives on Terrorism 6(2): 158-159.

Shapiro JN and Fair CC (2010) Understanding support for islamist militancy in pakistan. International Security 34(3): 79-118.

Smelser NJ (1962) Theory of collective behavior. New York: Free Press.

Stein B (2015) Baltimore breaks down: A political class unable to lead and unwilling to confront the rioters and criminals. The Spectator April(http://spectator.org/articles/62534/baltimorebreaks-down).

Stohl M (1983) The international network of terrorism. Journal of Peace Reearch 20(1): 59-66.

Tilly C (1978) From Mobilization to Revolution. Massachusetts: Addison-Wesley.

Wilkinson SI (2009) Riots. Annual Review of Political Science 12: 329-343. 